ABDIMAS: Jurnal Pengabdian Masyarakat Universitas Merdeka Malang
Vol.7(1) February 2022, 158-165
U-ISSN: 2721-138X e-ISSN: 2548-7159
Uttp://jurnal.unmer.ac.id/index.php/jpkm

\title{
Capacity building of farmers in developing fresh flower business in Berjo Village, Ngargoyoso District
}

\section{Peningkatan kapasitas petani dalam pengembangan usaha bunga potong di Desa Berjo Kecamatan Ngargoyoso}

\author{
Suminah', Padmaningrum Dwiningtyas', Anantanyu Sapja1, Kristiyanto Agus² \\ ${ }^{7}$ Departemen Penyuluhan dan Komunikasi Pertanian, Fakultas Pertanian, ${ }^{2}$ Departemen Pendidikan Olah Raga Fakultas \\ Keolahragaan, Universitas Sebelas Maret \\ Jl. Ir. Sutarmi No.36, Surakarta, 57126, Indonesia
}

\author{
ARTICLE INFO: \\ Received: 2021-08-30 \\ Revised: $2021-10-28$ \\ Accepted: 2021-12-11 \\ Keywords: \\ Empowerment, \\ Farmers, Fresh flowers, \\ Marketing, Partnerships
}

\begin{abstract}
Fresh flowers potentially become an alternative business for Berjo farmers, Karanganyar District. Berjo Flora is of a farmer group that engages in the fresh flowers business, but the venture still has some obstacles such as cultivation skills, business diversification, business management, marketing, and business motivation. Therefore, this Program Kemitraan Masyarakat (PKM) is undertaken as an effort to solve the problem in the form of; (1) chrysanthemum flower cultivation training; (2) business motivation, management, and online marketing; (3) flower bouquet training. Partners in this program consist of 14 members of Berjo Flora farmer group that are active as fresh flowers farmers. Results of this effort are: (1) improved business motivation and skills of the fresh flowers farmers; (2) establishment of marketing network and information exchange between fresh flower farmer communities.
\end{abstract}

(c) 2022 Abdimas: Jurnal Pengabdian Masyarakat Universitas Merdeka Malang This is an open access article distributed under the CC BY-SA 4.0 license (https://creativecommons.org/licenses/by-sa/4.0/)

How to cite: Suminah, S., Dwiningtyas, P., Sapja, A., \& Agus, K. (2022). Capacity building of farmers in developing fresh flower business in Berjo Village, Ngargoyoso District. Abdimas: Jurnal Pengabdian Masyarakat Universitas Merdeka Malang, 7(1), 158-165. https://doi.org/10.26905/abdimas.v7i1.6299

\section{PENDAHULUAN}

Produktivitas bunga potong dalam satuan tangkai di Indonesia menurut (Subdirektorat Statistik Hortikultura, 2018), dari tahun 2014 hingga tahun 2018 mengalami peningkatan yang diikuti dengan peningkatan luas lahan. Tahun 2014 hingga tahun 2018 produksi bunga potong mengalami peningkatan sebesar $14,79 \%$ mencapai 869.526 .274 tangkai. Hal itu diikuti dengan peningkatan luas panen lahan sebesar 15,79\% dari tahun 2014 sampai 2018. Selama kurun waktu 2017-2018 pemanfaatan potensi bunga potong Indonesia diwujudkan melalui ekspor, dengan negara tujuan Amerika Serikat, Selandia Baru, Belanda, Jerman, Korea, Singapura, Jepang, dan Kuwait (Subdirektorat Statistik Hortikultura, 2018).

Jawa Tengah memberikan kontribusi yang cukup besar yaitu sebanyak 69,5\% dalam bentuk bunga potong khususnya jenis krisan, mawar, sedap malam, dan anggrek dengan total produksi sebesar 
183.512.495 tangkai (Subdirektorat Statistik Hortikultura, 2018). Produsen tanaman florikultura tersebut tersebar di beberapa daerah, salah satunya Kabupaten Karanganyar. Dengan potensi wilayah 77.378,64 Ha (Hapsari, 2014) dan di antaranya dataran tinggi sangat sesuai dengan karakteristik lokasi budidaya bunga potong yang baik yaitu pada ketinggian 560-1400 mdpl (Herlina, 2013). Pada tahun 2018 bunga potong yang dihasilkan sebanyak 1.101.101 tangkai (Statistik Hortikultura Jawa Tengah, 2019).

Dari beragam wilayah penghasil bunga potong di Kabupaten Karanganyar, Desa Berjo merupakan salah satu desa dengan potensi menarik. Desa yang masuk pada wilayah Kecamatan Ngargoyoso ini terletak di ketinggian 900-1000 mdpl. Topografi, kondisi geografis, dan rata-rata suhu di Desa Berjo cocok dimanfaatkan untuk budidaya tanaman bunga potong. Petani bunga potong di desa banyak yang membudidayakan bunga potong, di antaranya tergabung dalam kelompok tani bunga potong Kelompok Berjo Flora. Kelompok ini beranggotakan 14 petani dengan rentang usia antara 16-43 tahun. Dinamika kelompok Berjo Flora cukup aktif, dilihat dari pertemuan rutin, aktivitas usaha budidaya, serta aktifnya forum diskusi dalam rangka saling tukar ide dan gagasan perkembangan usaha antar anggota.

Usaha bunga potong yang dijalankan kelompok Berjo Flora terbagi atas tanaman utama dan penunjang. Tanaman utama biasanya menjadi bunga utama yang jumlahnya lebih banyak dibandingkan dengan tanaman penunjang, seperti krisan, panca warna, dan garbera. Bunga potong utama dibutuhkan banyak sehingga perlu lahan luas untuk membudidayakannya. Adapun tanaman penunjang merupakan pelengkap dari bunga potong, di antaranya peacock, sedap malam, pilo, andong merah, songof india, leader leaf, dan marbel.

Kelebihan dari tanaman bunga potong adalah relatif mudah ditanam, yakni sebagai tanaman tahunan yang sekali tanam bisa dipanen berkali-kali hingga bertahun-tahun. Jenis bunga yang membutuhkan perawatan cukup intensif hanya bunga krisan, karena penanaman dilakukan dengan sekali panen (tanaman semusim) dan harus ditanam pada greenhouse.

Beberapa bunga potong dalam proses produksinya tergolong mudah. Petani hanya membutuhkan satu kali pembelian bibit untuk bisa panen terus-menerus kemudian juga bisa dikembangbiakan untuk diperbanyak. Semua bunga potong yang dibudidayakan di Desa Berjo dapat terus dikembangbiakkan kecuali tanaman bunga krisan, dimana pada umumnya petani membeli bibit untuk sekali panen. Meskipun beberapa petani sudah mencoba mengembangkan bunga krisan untuk dibibitkan sendiri untuk masa tanam berikutnya. Cara ini bisa mengurangi biaya produksi untuk pembelian bibit, di samping menjaga kualitas bibit yang terpercaya. Kemudahan petani dalam produksi bunga dan perbanyakan bibit serta potensi pasar ini lah yang menjadi kekuatan pengembangan bunga potong di Desa Berjo.

Potensi produksi bunga potong di desa ini cukup baik dan berkualitas karena keterampilan petani dalam budidaya yang baik. Dalam aspek pemasaran bunga potong terdapat kategori standar (grade) berdasarkan kualitas bunga yang dihasilkan seperti ketinggian tangkai bunga dan kesegaran serta penampakan bunga, yakni standar (grade) AA, A, B, dan C. Bunga potong yang dimiliki petani Desa Berjo rata-rata berstandar yang baik bahkan masuk standar toko.

Namun demikian petani bunga potong khususnya kelompok Berjo Flora masih menemui hambatan dalam hal pemasaran bunga potong. Selama ini bunga potong hanya dititipkan kepada kerabat atau penjual bunga potong di Kota Solo. Kelompok ini belum memasarkan bunga potong secara online melalui aplikasi-aplikasi e-commerce yang ada. Hal tersebut membuat masyarakat luas belum mengetahui adanya sentra bunga potong di Desa Wisata Berjo. Motivasi anggota kelompok terhadap usaha bunga potong juga masih relatif rendah dimana sebagian anggota kelompok masih ragu dalam mengelola usaha bunga potong. Termasuk pengetahuan petani dalam budidaya bungan potong juga masih relatif rendah. Pelatihan budidaya bunga krisan untuk meningkatkan pengetahuan petani (Kurniawansyah, 2018), untuk itu maka diperlukan peningkatan pengetahuan dan keterampilan pada petani. 
ABDIMAS: Jurnal Pengabdian Masyarakat Universitas Merdeka Malang

Volume 7, No 1, February 2022: 158-165

Pengelolaan usaha bunga juga belum maksimal dilihat dari skala tanam yang hanya mengambil sebagian dari lahan petani juga tingkat keseriusan pengelolaan yang masih relatif rendah. Kurangnya pengetahuan kelompok mitra terkait sistem manajemen dan pembukuan usaha, menjadikan kurang teraturnya sistem tata kelola keuangan. Selain itu, hambatan dalam aspek keterampilan membuat diversifikasi produk bunga potong, seperti rangkaian bunga untuk ucapan, maupun bunga potong untuk dekorasi pernikahan juga menjadi isu yang perlu diatasi untuk mengangkat produktivitas petani bunga potong.

Dengan demikian, pengabdian masyarakat dengan mitra Kelompok Tani Berjo Flora ini dilakukan dengan beberapa tujuan, yakni: (1) Meningkatkan pengetahuan dan motivasi petani dalam membudidayakan bunga krisan; (2) Meningkatkan pengetahuan dan keterampilan petani dalam manajemen usaha serta diversifikasi usaha bunga potong; (3) Meningkatkan motivasi petani dalam usaha bisnis bunga potong secara berkelanjutan dan menguntungkan. Pemberian motivasi usaha kepada petani dapat memotivasi petani (Evita et al., 2016).

Adapun solusi yang ditawarkan dalam program kemitraan masyarakat (PKM) ini dengan memberikan kegiatan pelatihan kepada petani sesuai kebutuhan petani (Rohmah, 2018). Sehingga pelatihan tersebut dapat mengatasi masalah dan kekurangan yang dimiliki petani (Tilon, 2013). Adapun kegiatan tersebut sebagai berikut: (1) Pelatihan membuat buket rangkaian bunga (untuk ucapan selamat, belasungkawa, dan lainnya), pembuatan bunga kering, juga pembuatan souvenir dari bunga kering dan lainlain yang selanjutnya akan dipasarkan secara online; (2) Pelatihan pemasaran secara online; (3) Pelatihan motivasi usaha bagi anggota kelompok.

\section{METODE}

Berdasarkan permasalahan yang dihadapi oleh Kelompok Tani Berjo Flora Desa Berjo maka metode kegiatan yang dilakukan adalah memberikan edukasi, fasilitasi, dan pendampingan sebagai berikut: (1) Koordinasi dan sosialisasi dengan stakeholders terkait (kelompok tani dan perangkat desa) berkaitan dengan rencana pelaksanaan kegiatan pengabdian kepada masyarakat yang dijalankan; (2) Pelaksanaan pelatihan budidaya bunga krisan untuk meningkatkan pengetahuan dan keterampilan petani dalam budidaya bunga krisan, dengan cara pelatihan di lokasi sentral bunga potong di Bandungan; (3) Pelaksanaan pelatihan membuat karangan bunga meningkatkan keterampilan petani dalam diversifikasi produk yaitu dengan dilatih untuk membuat karangan bunga berbagai ucapan (bela sungkawa, pernikahan, pengukuhan, pembukaan kantor baru, dan sebagainya), buket (untuk berbagai ucapan selamat pada wisudan), bunga rangkai dalam vas dan difasilitasi semua peralatannya; (4) Pelatihan pemberian motivasi usaha kepada petani. Kegiatan tersebut dilakukan dengan pemberian motivasi kepada petani agar lebih serius dan tekun dalam menjalankan usaha bunga potong; (5) Pendampingan kepada kelompok tani pasca pelatihan, untuk memastikan bahwa petani telah melakukan apa yang sudah diberikan, selain itu dalam pendampingan ini membantu kelompok tani jika masih mengalami kendala dalam melaksanakannya.

\section{HASIL DAN PEMBAHASAN}

\section{Persiapan dan Pelaksanaan Kegiatan}

Sebagai langkah awal sebelum pelaksanaan kegiatan pengabdian dengan mitra kelompok tani Berjo Flora Desa Berjo, tim pelaksana melaksanakan sosialisasi dan koordinasi sebagai upaya memaksimalkan pelaksanaan kegiatan. Kegiatan sosialisasi dan koordinasi bersama mitra dilakukan pada tanggal 10 April 2021, bertempat di rumah Ketua Kelompok Tani Berjo Flora di Pabongan, RT 
03/RW 04, Berjo, Kecamatan Ngargoyoso, Kabupaten Karanganyar. Kegiatan tersebut dihadiri oleh perwakilan anggota kelompok tani Berjo, kepala dusun, dan tim pelaksana. Hasil rapat koordinasi dan sosialisasi menghasilkan kesepakatan program kegiatan dan waktu pelaksanaan kegiatan. Adapun aktivitas terlampir pada Gambar 1.

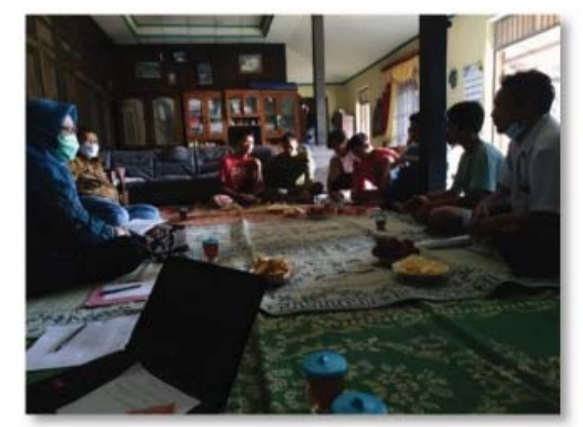

Gambar 1. Koordinasi dan sosialisasi kegiatan pengabdian kepada masyarakat

Dari hasil sosialisasi dan koordinasi diperoleh kesepakatan pelaksanaan kegiatan berikutnya yaitu, pelatihan budidaya bunga krisan yang dilakukan pada tanggal pada 24 April 2021. Adapun pelaksanaan dilakukan tim pengabdian dan kelompok tani berangkat bersama-sama ke sentra bunga potong di Bandungan untuk belajar budidaya bunga krisan. Setelah itu, juga dilakukan pelatihan merangkai bunga dan motivasi usaha yang pada awalnya direncanakan pada Mei 2021 namun dikarenakan bertepatan dengan hari raya umat muslim maka pelaksanaan diundur menjadi tanggal 10 Juni 2021. Selain itu, untuk memperluas pemasaran disepakati juga untuk menjual secara online, dalam hal ini kelompok membutuhkan Android untuk pemasaran online. Hasil kesepakatan kelompok tani diberikan Android dan pendampingan dalam mengelola pemasaran online.

\section{Pelatihan budidaya bunga krisan}

Pelatihan budidaya bunga krisan dilakukan pada tanggal 24 April 2021, dilakukan di Kecamatan Bandungan Kabupaten Semarang tepatnya di Kelompok Tani Gemah Ripah Dusun Clapar RT 04/RW 05 yaitu di lahan petani. Pelatihan budidaya krisan dihadiri oleh anggota kelompok tani, tim pengabdian, serta perwakilan dari kelompok tani Gemah Ripah yang merupakan kelompok tani bunga potong di Bandungan yang sudah lebih dulu memiliki pengalaman dan merintis usaha bunga potong khususnya krisan (Gambar 2).

Materi pelatihan meliputi aspek budidaya dari persiapan lahan, pembibitan, pemeliharaan, sampai panen bunga krisan. Di antara materi yang diberikan adalah mengenai karakteristik bunga krisan, syarat budidaya bunga krisan, pengolahan tanah, pemasangan greenhouse, penanaman benih krisan, penyiraman tanaman, perompesan daun senescens (daun tua), pemotesan kuncup bunga, pengendalian gulma, pengendalian waktu panen, pencatatan kegiatan, serta analisis usaha tani bunga krisan. Pemberian materi berupa teori dalam pelatihan dapat disebut sebagai metode ceramah (Adriansyah et al., 2020). Adapun melalukan kegiatan praktik bersama berupa metode demonstrasi (Mizan \& Cacik, 2020)

Semua peserta pelatihan antusias dalam menjalankan pelatihan budidaya bunga krisan. Hal ini dapat dilihat dari semangat kelompok untuk mengikuti kegiatan dari awal hingga akhir (Lapisa et al., 2017; Gardjito et al., 2014). Peserta juga aktif melakukan diskusi dan tanya jawab kepada narasumber (Aisyah \& Mahanani, 2017). Setelah pelatihan peserta banyak yang termotivasi untuk meningkatkan 
ABDIMAS: Jurnal Pengabdian Masyarakat Universitas Merdeka Malang Volume 7, No 1, February 2022: 158-165

budidaya dan menseriusi budidaya bunga krisan dengan mulai membeli peralatan keperluan menanan bunga krisan.

\section{Pelatihan membuat rangkaian bunga dan motivasi usaha}

Pelatihan dilakukan di Joglo Studio Tani yang berada di Dusun Tagung RT 02/RW 02 Desa Berjo Kecamatan Ngargoyoso Kabupaten Karanganyar yang diikuti oleh peserta dari anggota kelompok tani Berjo Flora dan masyarakat pendatang yang juga turut antusias mengikuti pelatihan (Gambar 3). Hal ini menandakan bahwa program kemitraan memberi semangat dan angin segar bagi anggota kelompok serta masyarakat untuk lebih banyak belajar mengenai diversifikasi usaha bunga potong sehingga dapat meningkatkan keterampilan dan menunjang usaha (Hermawan \& Suryono, 2016).
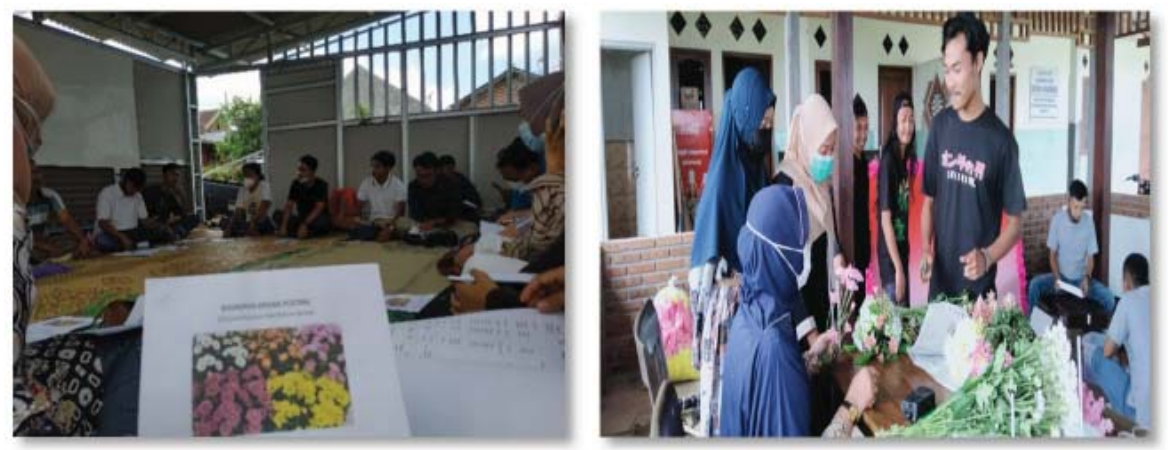

Gambar 2. Kegiatan pelatihan budidaya bunga krisan

Gambar 3. Kegiatan pelatihan motivasi dan merangkai bunga
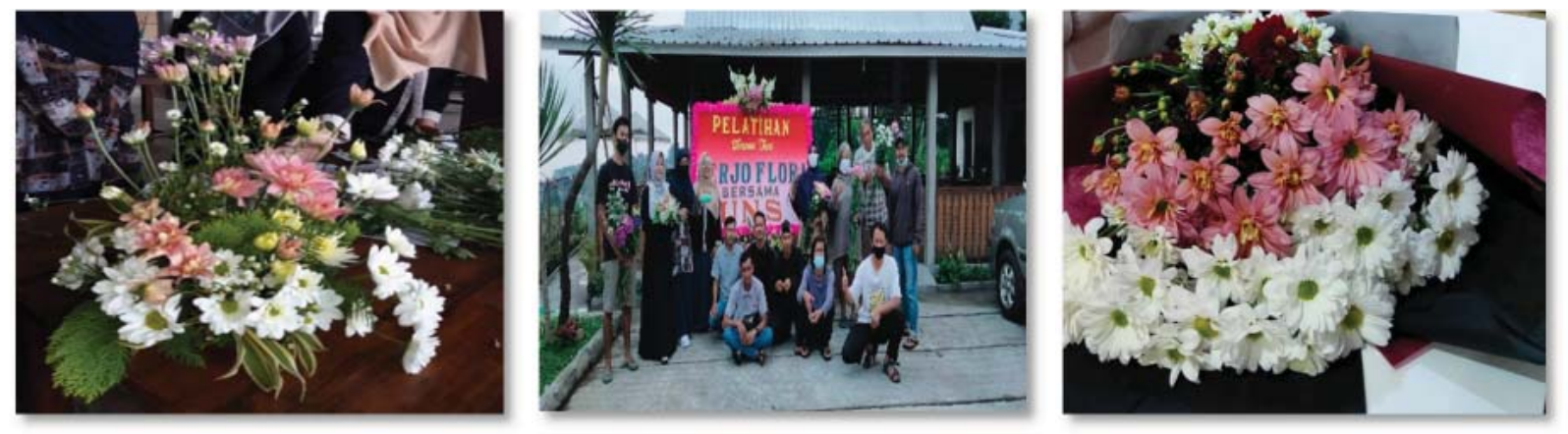

Gambar 4. Hasil karya pelatihan

Adapun proses pembuatan karangan bunga dengan menyiapkan alat dan bahan berupa, bambu penyangga, papan, bunga potong, bunga plastik, lem bakar, cat, dan gabus. Pertama-tama yaitu merangkai papan karangan dengan menempelkan bunga plastik pada keliling papan, selanjutnya membuat tulisan dari gabus yang dipotong-potong sesuai tulisan yang dibutuhkan, selanjutnya mengecat tulisan dari gabus yang sudah dibentuk tulisan dan ditempelkan pada papan. Cat yang digunakan adalah cat warna tekstil dengan tekstur tidak begitu cair dan kental (Sari \& Damayanti, 2020). Cat ini bisa tahan lama dan tidak mudah pudar (Kaseke, 2016). Kemudian setelah mengecat papan dipasang dengan bambu, kemudian bunga potong disusun untuk mempercantik karangan bunga. Adapun pembuatan bunga meja cukup sederhana namun dibutuhkan kreativitas dan pembiasaan untuk merangkainya. Pada saat 
merangkai narasumber memberikan teknik-teknik khusus untuk merangkai dengan baik. Beberapa contoh hasil karya peserta tersaji pada Gambar 4.

Serangkaian kegiatan pelatihan pengabdian bersama mitra kelomopok tani telah selesai dilaksanakan. Tim Program Kemitraan Masyarakat juga melakukan pendampingan kepada kelompok tani. Pendampingan dilakukan bersamaan dengan monitoring dan evaluasi kegiatan. Selain itu, tim program kemitraan juga membantu memberikan alternatif pemasaran melalui pemasaran online dengan memberikan Android kepada kelompok mitra. Pemberian Android dimaksudkan agar memudahkan mitra mengelola pemasaran online untuk memperluas pasar. Pemasaran online dimulai dengan membuat media sosial berupa Instagram dengan nama Berjo Flora sebagai wadah pemasaran hasil produksi anggota kelompok mitra. Instagram Berjo Flora saat ini berisi tentang postingan kegiatan dan hasil produksi dari karya-karya yang sudah pernah dibuat oleh anggota-anggota kelompok mitra.

Monitoring dan evaluasi dilakukan sebagai bentuk untuk mengetahui perkembangan hasil pelatihan dan melihat sejauh mana hasil pelatihan sudah diterapkan oleh mitra, apakah ada kendala di dalam pelaksanaan dari hasil pelatihan yang sudah dilakukan. Apabila masih ada kendala dalam praktik pelaksanaannya maka dapat dicarikan solusi bersama. Hasil monitoring dan evaluasi yang telah dilakukan oleh tim pelaksana yaitu untuk kegiatan kelompok tani dalam mempraktikan budidaya bunga potong semakin giat dilakukan terbukti dengan adanya peningkatan luas area tanam, selain itu pemasaran yang dilakukan secara offline semakin ramai, tetapi sementara ini pemasaran yang dilakukan secara online masih belum begitu menjadi prioritas. Hal ini disebabkan karena anggota belum terbiasa mengelola akun bisnis berbasis media sosial.

Tabel 1. Peningkatan kemampuan kelompok

\begin{tabular}{lll}
\hline \multicolumn{1}{c}{ Aktivitas Mitra } & \multicolumn{1}{c}{ Sebelum Pelatihan } & \multicolumn{1}{c}{ Sesudah Pelatihan } \\
\hline Budidaya bunga potong & $\begin{array}{l}\text { Beberapa anggota kurang melakukan } \\
\text { perawatan, masih ada yang belum ikut } \\
\text { menanam bunga potong, luas lahan tanam } \\
\text { 6,25 ha, ada 4 greenhouse yang digunakan }\end{array}$ & $\begin{array}{l}\text { Perawatan lebih teratur, anggota semakin } \\
\text { aktif berpartisipasi menanam, luas lahan } \\
\text { tanam meningkat menjadi 7 ha, meningkat } \\
\text { menjadi } 7 \text { greenhouse }\end{array}$ \\
Kurang semangat & Semangat tinggi, motivasi meningkat \\
Dinamika Kelompok & Beberapa anggota masih kurang aktif & Partisipasi anggota menjadi lebih aktif \\
Omset Penjualan & Kurang lebih 24 juta per panen pada 4 & Kurang lebih 42,5 juta per panen pada 7 \\
& greenhouse & greenhouse \\
Pendapatan & Dari omset penjualan Rp 24.000.000 & Dari omset penjualan Rp 42.500.000 \\
dikurangi pengeluaran sebanyak Rp & dikurangi pengeluaran sebanyak Rp \\
12.000.000 = Rp 12.000.000,- per panen & Bunga potong, karangan bunga, buket, \\
Produk & Bunga potong & Bung \\
Pemasaran & Gethuk tular & Gethuk tular, online (Instagram) \\
Manajemen Kelompok & Belum ada pembukuan & Sudah dibuat pembukuan sederhana \\
\hline
\end{tabular}

Secara keseluruhan kegiatan pengabdian yang telah dilakukan tim pelaksana program kemitraan masyarakat di Desa Berjo memberikan banyak perubahan. Perubahan tersebut dapat dilihat dari berbagai aktivitas kelompok tani. Aktivitas tersebut di antaranya, yaitu budidaya bunga potong, motivasi usaha, dinamika kelompok, omset penjualan, produk, cara pemasaran, dan manajemen kelompok. Hal ini berarti ada perbedaan aktivitas dan pendapatan kelompok tani sebelum ada kegiatan pengabdian dan sesudah ada kegiatan pengabdian kepada masyarakat. 
ABDIMAS: Jurnal Pengabdian Masyarakat Universitas Merdeka Malang

Volume 7, No 1, February 2022: 158-165

\section{SIMPULAN DAN SARAN}

Bunga potong memiliki prospek cerah sebagai upaya peningkatan pendapatan petani Desa Berjo. Melalui kegiatan pemberdayaan pada kelompok tani Berjo Flora, anggota kelompok tani termotivasi untuk menjalankan usaha bunga potong melalui perluasan area tanam, peningkatan aspek usaha dalam bentuk pembuatan aneka karangan bunga, mengelola usaha dengan manajemen yang baik, menerapkan pemasaran online, serta mengembangkan jaringan dengan petani bunga dari daerah lain. Adanya kegiatan ini secara nyata berkontribusi pada semakin meningkatnya lahan tanam bunga potong di Desa Berjo, peningkatan pendapatan kelompok tani, dan manajemen penjualan yang lebih baik.

Perlu adanya upaya pendampingan dari berbagai pihak termasuk dukungan dari pemerintah daerah Kabupaten Karanganyar dalam upaya menjaga keberlanjutan usaha sekaligus mengembangkan Desa Berjo sebagai desa sentra bunga potong di Kabupaten Karanganyar. Pengembangan usaha ini tidak akan optimal hasilnya apabila tidak ada tindak lanjutnya. Untuk itu, selain pendampingan diperlukan penyadaran dan motivasi kepada pemuda tani secara terus menerus agar semakin banyak pemuda tani yang mau berbudidaya bunga potong. Selanjutnya perlu adanya outlet toko floris yang memasarkan baik bunga potong maupun produk turunannya (seperti karangan bunga, buket bunga, dan sebagainya) di dipusat kota untuk memperluas pemasaran sekaligus agar bunga potong Desa Berjo dikenal secara luas.

\section{DAFTAR PUSTAKA}

Adriansyah, M. A., Sintara, I. D., Pramujie, G. V. C., \& Salsabila, A. (2020). Meningkatkan komitmen organisasi melalui pelatihan manajemen diri. PLAKAT (Pelayanan Kepada Masyarakat), 2(1), 81. http://dx.doi.org/10.30872/plakat.v2i1.3827

Aisyah, E. N., \& Mahanani, P. (2017). Pelatihan menulis artikel ilmiah bagi guru sekolah dasar dan taman kanak-kanak Kecamatan Tajinan Kabupaten Malang. Jurnal Abdimas Pedagogig, 1(1), 22-26. http://dx.doi.org/10.17977/um050v1i1p\%25p

Evita, D., Mursyid, A., \& Siswati, T. (2016). Pelatihan meningkatkan pengetahuan dan keterampilan kader puskesmas dalam penerapan standar pemantauan pertumbuhan belita di Kota Bitung. Jurnal Gizi Dan Dietetik Indonesia (Indonesian Journal of Nutrition and Dietetics), 1(1), 15. http://dx.doi.org/10.21927/ijnd.2013.1(1).15-21

Gardjito, A. H., Al Musadieq, M., \& Nurtjahjono, G. E. (2014). Pengaruh motivasi kerja dan lingkungan kerja terhadap kinerja karyawan (studi pada karyawan bagian produksi PT. Karmand Mitra Andalan Surabaya). Jurnal Administrasi Bisnis 51 Universitas Brawijaya, 13(1), 1-8.

Hapsari, W. R. (2014). Draft Karanganyar dalam angka 2014. Karanganyar: BPS Kabupaten Karanganyar.

Herlina, I. S. (2013). Fasilitas penelitian, pembudidayaan, dan wisata tanaman mawar di Batu. Jurnal Teknik Pomuk Petra, 1(2).

Hermawan, Y., \& Suryono, Y. (2016). Partisipan masyarakat dalam penyelenggaraan programprogram pusat kegiatan belajar masyarakat ngudi kapinteran. JPPM (Jurnal Pendidikan Dan Pemberdayaan Masyarakat), 7(4), 97-108. https://doi.org/10.21831/jppm.v3i1.8111

Kaseke, H. F. G. (2016). Ekstraksi pewarna makanan dari akar kelapa. Buletin Palma, 14(2), 95-99. http://dx.doi.org/10.21082/bp.v14n2.2013.95-99 
Capacity building of farmers in developing fresh flower business in Berjo Village, Ngargoyoso District Suminah, Padmaningrum Dwiningtyas, Anantanyu Sapja, Kristiyanto Agus

Kurniawansyah, I. S. (2018). Pelatihan peningkatan pengetahuan dan keterampilan memilih obat mata bagi tenaga Kesehatan Desa Cilayung Kecamatan Jatinangor. Jurnal Aplikasi Iptek Untuk Masyarakat, 7(4), 265-268. https://doi.org/10.24198/dharmakarya.v7i4.19693

Lapisa, R., Basri, I. Y., Arif, A., \& Saputra, H. D. (2017). Peningkatan kompetensi siswa melalui pelatihan auto cad. INVOTEK: Jurnal Inovasi Vokasional dan Teknologi, 17(2), 119-126. https://doi.org/10.24036/invotek.v17i2.82

Mizan, S., \& Cacik, S. (2020). Pelatihan hidrochili (tanaman cabai secara hidroponik) pada keluarga penerima manfaat Desa Prambonwetan Kecamatan Rengel-Tuban. Community Development Journal, 4(1), 102-106. https://doi.org/10.33086/cdj.v4i1.1073

Rohmah, N. F. (2018). Pelatihan dan pengembangan sumber daya manusia. Intizam: Jurnal Manajemen Pendidikan Islam, 2(1), 1-11.

Sari, Y. D. Y., \& Damayanti, A. (2020). Penggunaan pewarna sintesis dan alam pada lukis kain. Jurnal Garina, 12(2), 1-11.

Statistik Hortikultura Jawa Tengah. (2019). Statistik pertanian hortikultura Provinsi Jawa Tengah 20162018. Badan Pusat Statistik Indonesia.

Subdirektorat Statistik Hortikultura. (2018). Statistik tanaman hias Indonesia 2018. Badan Pusat Statistik Indonesia.

Tilon, D. A. (2013). Pelatihan dan pengembangan sumber daya manusia pada restoran A\&W di City of Tomorrow Surabaya. Agora, 1(3), 1-9. 